MaPan : Jurnal Matematika dan Pembelajaran

p-ISSN: 2354-6883 ; e-ISSN: 2581-172X

Volume 9, No 2, Dec 2021 (197-217)

DOI: https://doi.org/10.24252/mapan.2021v9n2a1

\title{
MISCONCEPTION ANALYSIS IN TERMS OF STUDENT LEARNING STYLES
}

\author{
Winda Rahma Fauziah'), Arif Muchyidin²) \\ 1,2IAIN Syekh Nurjati Cirebon \\ 1,2Jl. Perjuangan By Pass Cirebon, Indonesia \\ E-mail: windaoh123@gmail.com¹),wak_badjra@yahoo.com²)
}

Received June 23, 2020; Revised November 24, 2021; Accepted December 23, 2021

\begin{abstract}
:
This study aims to determine students' misconceptions in social arithmetic material when viewed from student learning styles. The population in this study was 28 students of class VII F MTs Negeri 5 Cirebon. The research form used in this study is qualitative research, with a research strategy that is a case study. Data collection techniques used were 1) the observation method, 2) the tests method, 3) the questionnaire method, 4) the interview method is conducted for students who experience misconceptions after adjusting to the student's learning style. The results of this study are 1) Students who have a visual learning style do not experience misconceptions in mathematical concepts, but students experience misconceptions in the process of counting and translation. 2) Students who have auditorial learning styles, there are no misconceptions in mathematical concepts, but students experience errors in the final calculation process. 3) Students who have kinesthetic learning styles it is suspected that students have conceptual misconceptions because students do not understand the concept of the process including students who do not understand the mathematical formulas and values that must be used and students do not understand calculations. In general, the causes of misconceptions in students who have visual learning styles, auditory and kinesthetic, are derived from student understanding and teacher learning methods.
\end{abstract}

Keywords: Misconception, Learning Style, Social Arithmetic

\section{ANALISIS MISKONSEPSI DITINJAU DARI GAYA BELAJAR SISWA}

\begin{abstract}
Abstrak:
Penelitian ini bertujuan untuk mengetahui miskonsepsi siswa yang terjadi pada materi aritmatika sosial jika dilihat dari gaya belajar siswa. Populasi dalam penelitian ini adalah siswa kelas VII F MTs Negeri 5 Cirebon sebanyak 28 siswa. Bentuk penelitian yang digunakan dalam penelitian ini adalah penelitian kualitatif, dengan strategi penelitian yaitu studi kasus. Teknik pengumpulan data yang digunakan adalah 1) metode observasi, 2) metode tes, 3) metode angket, 4) metode wawancara dilakukan terhadap siswa yang mengalami miskonsepsi setelah disesuaikan dengan gaya belajar siswa. Hasil penelitian ini adalah 1) Siswa yang memiliki gaya belajar visual tidak mengalami miskonsepsi dalam konsep matematika, tetapi siswa mengalami miskonsepsi dalam proses berhitung dan menerjemahkan. 2) Siswa yang memiliki gaya belajar auditorial, tidak terdapat miskonsepsi dalam pembelajaran
\end{abstract}


terkait konsep matematika, tetapi siswa mengalami kesalahan dalam proses perhitungan akhir. 3) Siswa yang memiliki gaya belajar kinestetik diduga siswa mengalami miskonsepsi konseptual karena siswa tidak memahami konsep proses termasuk siswa yang tidak memahami rumus matematika dan nilai yang harus digunakan dan siswa kurang memahami perhitungan. Secara umum penyebab miskonsepsi yang terjadi baik pada siswa yang memiliki gaya belajar visual, auditori, maupun kinestetik bersumber dari pemahaman siswa dan metode pembelajaran guru.

Kata Kunci: Miskonsepsi, Gaya belajar, Aritmatika sosial

How to Cite: Fauziah, W. R., \& Muchyidin, A. (2021). Misconception Analysis in Terms of Student Learning Styles. MaPan : Jurnal Matematika dan Pembelajaran, 9(2), 197-217. https://doi.org/10.24252/mapan.2021v9n2a1.

\section{INTRODUCTION}

$\mathrm{I}$ n Indonesia, mathematics is a compulsory subject taught from elementary school, junior high school, high school, and college because mathematics is considered essential and valuable in human life (Fauziah, 2019). According to the National Research Council (NRC) of the United States, if a student succeeds in learning mathematics, the door to a brilliant life career will open wide for him. A country with mathematics will prepare its citizens to compete in economics and technology (Sutama, 2019).

As is well known, mathematics is a discipline with specific characteristics compared to other fields. It can be said that mathematics is related to abstract ideas or concepts (Alfiani, Muchyidin, \& Izzati, 2019; Istiyani, Muchyidin, \& Raharjo, 2018; Kamil, 2013), arranged hierarchically with deductive reasoning (Muchyidin, 2014; Rochmad, 2010), namely the truth of a concept or reasoning obtained as a result of the previous truth so that the link between concepts or reasoning in mathematics is fixed or consistent.

Along with the development of science and technology in education, education influences human life to create quality and potential human resources. Education is a process of changing behaviour (Pane, 2017; Rahman, Mason, \& Yusof, 2012) and one's ability towards progress and improvement (Bok, 2017; Muhardi, 2004). Education cannot be separated from the objectives to be achieved because the achievement or failure of educational goals is a benchmark of academic success (Anwar, 2014; Muchyidin \& Amin, 2012). 
The success of education is measured in a learning process carried out or applied. The learning process applied to mathematics subjects emphasizes the initial conceptions already known to students (Aledya, 2019), which can then be upgraded to a higher process as the formation of new knowledge. Most misconceptions experienced by students are brought from previous levels of education, resulting in continuous misconceptions at different levels of education (Istiyani, Muchyidin, \& Raharjo 2018; Medina, 2015; Meriani, Muchyidin, \& Kusmanto, 2019). Not a few students fail or do not get good results in lessons because they tend not to know ways of learning that are effective and efficient. They mostly memorize lessons and absorb the knowledge gained without any filter in advance, so that often there are discrepancies between the knowledge taken with the actual concept (Alfiani, Muchyidin, \& Izzati, 2019). In reality, mathematics is not material to be memorized but requires more reasoning and understanding. As a result, many students have difficulty when given evaluation questions in test form, even though the structure of the question is almost the same as the practice questions that have been studied previously.

The Indonesian Ministry of National Education in Permendiknas, number 22 of 2006 (Kemendiknas, 2006), explained that the purpose of learning mathematics in elementary, junior high, high school, and vocational school is that students can understand mathematical concepts, explain the inter-conceptual relationships and apply concepts, flexibly, accurately, efficiently, and precisely in problem-solving. This purpose was determined with the hope that the inculcation concept could be built continuously from the basic to the upper levels. In addition to understanding concepts that are applied from the lowest level to the highest level, there is a characteristic that students must possess. One of the characteristics of these students is their learning styles. Student learning styles affect how students learn, determining how to learn more effectively (Magdalena, 2015; Rezaeinejad, Azizifar, \& Gowhary, 2015). A more effective way of learning can help capture and understand a subject matter.

Based on the description mentioned above, the problems regarding conception and learning style are exciting to study, especially the misconceptions that occur and are experienced by students in terms of their learning styles. Knowing students' mistakes in understanding more straightforward concepts and making improvements early will minimize the 
possibility of students experiencing mistakes in understanding more difficult or more complex lesson concepts.

One subject that is considered difficult by junior high school students is social arithmetic (Meilando, Idris, \& Murdiana, 2017). Social arithmetic is close to daily activities, such as buying and selling. This term was introduced in mathematics learning in grade $7^{\text {th }}$ (Yulianti, Juniati, \& Khabibah, 2018). For researchers, the problem of misconceptions involving the learning styles used by students when learning takes place is fascinating to study, hoping that the quality of learning in the classroom will change for the better.

\section{METHODS}

Based on the objectives to be achieved in research, the research form used is a qualitative research method, while the research strategy carried out is a case study. In the case of study research, the steps to be taken are observing, collecting data, analyzing information, and reporting results (Bungin, 2015). Thus a deep understanding of why can occur and the basis for further research will be obtained.

The research design used in this study is the single treatment design (one-shot case study). In this design, a group of research subjects received treatment, then measured the variables to be observed (Arikunto, 2013). In this study, the subjects taken were students of class VII F MTs Negeri 5 Cirebon who were suspected of having misconceptions in the subject matter of social arithmetic. In this study, subjects will be based on the diagnostic test results that students have carried out. Students selected to carry out the next stage tend to have a relatively high error rate in understanding concepts and are adjusted to learning styles that have previously been known from the learning style questionnaire that the students have filled in. The interviews were then conducted with six students who were taken based on the acquisition of scores as interview subjects to determine the factors that caused students to experience misconceptions in social arithmetic material.

\section{RESULTS AND DISCUSSION}

\section{Classification of Student Learning Styles}

According to DePorter and Hernacki (DePorter \& Hernacki, 2003), the learning style combines absorbing, organizing, and processing information. Each student must have their learning styles, which of course, differ from one 
student to another; if learning by the learning style that is owned, it can make students absorb the material provided more optimally.

This study uses a questionnaire given to students of class VII F MTs Negeri 5 Cirebon and filled in individually. This questionnaire is given to students to find out the grouping of student learning styles. The following are the results.

Table 1. Description of Grouping Student Learning Styles

\begin{tabular}{lcc}
\hline \multicolumn{1}{c}{ Learning Style } & Subject Number & Percentage \\
\hline \multirow{2}{*}{ Visual } & $10,27,21,7,9,26,25,24$, & \\
& $16,12,5,22,8,18,17,19$, & $80,57 \%$ \\
Auditorial & $1,20,6,4,2,11$ & \\
Kinesthetic & 15,23 & $8,64 \%$ \\
\hline
\end{tabular}

From table 1 above, it is known from a total of 27 students who filled out the questionnaire, 22 students classified as having a visual learning style were students who were very sharp insight, saw attitudes and movements, liked the demonstration, sensitivity to colours, understanding of artistic problems, and reactive to sound.

Two students are classified as having an Auditorial learning style; students with this learning style rely on hearing, remember well the teacher's explanation, express ideas a lot, are proficient in writing/writing assignments, and are happy to discuss. The remaining three people are classified as having kinesthetic learning styles, but one student is classified as having a kinestheticvisual learning style. Students with this learning style rely on limbs to give or receive information to remember it, find it difficult to remain silent, always want to move, and use natural objects as teaching material, like games and physical activities, like practice/experiments.

From the learning style grouping table above, students of class VII F MTs Negeri 5 Cirebon have different learning styles; it can be seen from the percentage that visual learning styles are very dominant compared to other learning styles. Teachers should not use learning methods that tend to only one learning style in the learning process. By knowing students' learning styles, teachers can use varied learning methods to deliver teaching material to the maximum extent accepted by students and help students in the learning process. 


\section{Analysis of the Type of Error Student Test Results Viewed from the Learning Style}

a. Students with a Visual Learning Style

1) Problem number 1

From the fragments of answers below, students answer correctly by the counting procedure in seeking profits. Nevertheless, students are still not consistently using mathematical symbols such as the sum, which is converted into dots. In the fragment of the answer, students allegedly did not experience concept misconceptions. Still, allegedly students experienced misconceptions of marks, and students made three mistakes in operating multiplication with a dot symbol. The possible cause of the sign misconception is the lack of the teacher's emphasis on mathematical signs or symbols, especially multiplication. In interviews conducted with students, students do misconceptions about these signs reflexively and unintentionally. Because usually, when students fill in math problems, the teacher is never questioned.

Table 2. Examples of Errors Student Answer in Problem Number 1

\begin{tabular}{ll}
\hline \multicolumn{1}{c}{ Student Answers } & \multicolumn{1}{c}{ Is there a Misconception? } \\
\hline & $\begin{array}{l}\text { The misconception of signs, } \\
\text { students write a dot which should } \\
\text { be multiplication sign }\end{array}$ \\
\hline
\end{tabular}

2) Problem number 2

The following are examples of fragments of student answers.

Table 3. Examples of errors student answer in problem number 2

\begin{tabular}{|c|c|}
\hline Student Answers & Is there a Misconception? \\
\hline 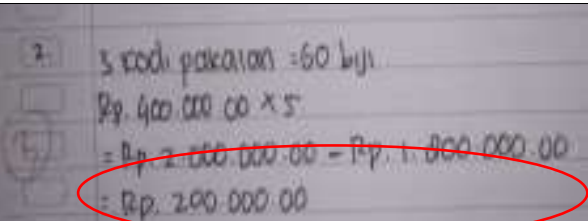 & $\begin{array}{l}\text { Misconceptions of strategies and } \\
\text { misconceptions of translation, there } \\
\text { is no formula, identity and also a } \\
\text { conclusion }\end{array}$ \\
\hline
\end{tabular}

From the students' answers above, students answer correctly by the profit-seeking procedure, but students do not write the identity of the problem known and asked then there is no conclusion at the end of 
the answer. Moreover, students do not write the profit formula. Students feel confused about converting units into scores units.

It is assumed that the students' answers did not experience concept misconceptions. However, students were expected to experience translation misconceptions because it was difficult to understand the story problem words to be converted into mathematical models. Allegedly, students experienced strategic misconceptions because students did not write the formulas. The cause of the misconception was thought to be due to the teacher's emphasis on understanding the importance of answering questions accompanied by the formula and the identity of the questions and conclusions. In interviews conducted with students, he experienced confusion in turning questions into mathematical models and determining the mathematical formula even though he could work on the problems without the formula.

3) Problem number 3

The following are examples of fragments of student answers.

Table 4. Examples of errors student answer in problem number 3

\begin{tabular}{cl}
\hline Student Answers & \multicolumn{1}{c}{ Is there a Misconception? } \\
\hline $3.20 \times 35.000 .00: 7.000=3.000 .00=7.000$ & $\begin{array}{l}\text { Strategy misconceptions because } \\
\text { they do not include formulas in } \\
\text { the process }\end{array}$ \\
\hline
\end{tabular}

From the students' answers above, students answer correctly according to the procedure of finding a discount and determining the price to be paid. Still, students immediately write down the answers without writing down the formula and identity of the questions as they are known and asked, then there is no conclusion at the end of the answer. Nevertheless, students are wrong in the calculating process in looking for prices to pay. Students should answer 28,000, but students answer 23,000.

From the student answers, it is suspected that students did not experience concept misconceptions, but students experienced strategy misconceptions because they did not include formulas in the process. And they are not being careful students in calculating the final results. 
Lack of teacher emphasis on students to include formulas and the importance of question identity in answering questions. In interviews that have been conducted with students, mention that students feel confused in determining the formula to be used. Students can only work on the problem without regard to the formula that must be written down, and students experience errors in the calculation process.

4) Problem number 4

The following are examples of fragments of student answers.

Table 5. Examples of errors student answer in problem number 4

\begin{tabular}{|c|c|}
\hline Student Answers & Is there a Misconception? \\
\hline 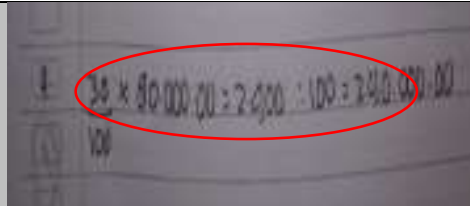 & $\begin{array}{l}\text { Concept misconceptions, because } \\
\text { students directly write answers in } \\
\text { an unstructured manner and } \\
\text { students' answers are incorrect }\end{array}$ \\
\hline
\end{tabular}

From the students' answers above, students answer correctly according to finding discounts by multiplying prices and per cent. Nevertheless, students immediately write down the answers without writing down the formula and identity of the questions as they are known and asked, then there is no conclusion at the end of the answer. Moreover, students only look for the discount value without looking for the final value to determine the price to pay. Also, students experience errors in the calculation process; students should answer 240,000, but students write with a value of 2,400 , - and also students should write a discount value with a nominal 24,000, not 240,000 -.

From the fragment of student answers, it is suspected that students experience concept misconceptions because they directly write answers in an unstructured manner. Students cannot answer the calculations correctly from looking for discounts. Allegedly students are in a hurry and are not careful in calculating. The results of interviews conducted by students said that he did not know the formula to find the price to be paid and felt confused when counting and did not know in the process. 


\section{5) Problem number 5}

From the students' answers below, students answer correctly according to looking for a single flower. Nevertheless, students immediately write down the answers without writing down the formula and identity of the questions as they are known and asked, then there is no conclusion at the end of the answer. And students are wrong in the counting process, students should write 96,000, but students write 960,000 .

Table 6. Examples of errors student answer in problem number 5

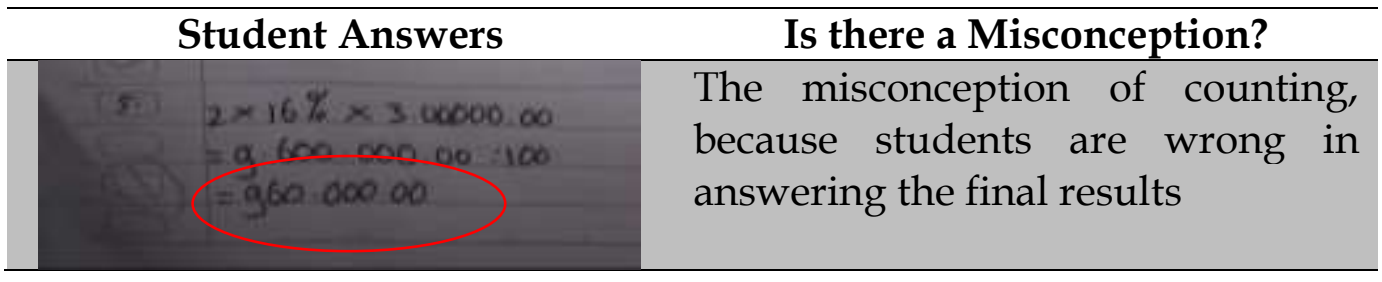

From the student answers, it is suspected that students did not experience concept misconceptions. However, it is suspected that students experience the misconception of translation and counting. Students are suspected of having a misconception because students are wrong in the counting process, and students cannot complete the counting process correctly. Students are not careful in writing excessive 0 (zero) nominal. The cause of the misconception of translation and counting was allegedly caused by the teacher, who did not emphasize writing down the identity of the question and how to do it quickly. In the interviews conducted with students, students said that he understood the workflow, but he was confused about how to do it, especially in the calculation process.

b. Students with an Auditorial learning style

1) Problem number 1

The following are examples of fragments of student answers.

Table 7. Examples of errors student answer in problem number 1

\begin{tabular}{cl}
\hline Student Answers & \multicolumn{1}{c}{ Is there a Misconception? } \\
\hline & $\begin{array}{l}\text { Concept misconceptions because } \\
\text { students do not understand how to } \\
\text { work on problems }\end{array}$ \\
\hline
\end{tabular}


From the fragments of students' answers above, students answer correctly according to the calculation procedure to determine the selling price of 1 and selling price two by multiplying the price by the number of salaks. However, the student does not substitute the total selling price $=$ selling price one + selling price two, and indirectly, students can not find the benefits obtained. Students answer the final results carelessly.

In fragmenting the students' answers, students are suspected of experiencing concept misconceptions because they do not understand how to work on problems. Moreover, there is a lack of students' understanding of calculating profit and looking for the total price. In interviews conducted with students, students said they did not understand the completion of problem number 1 . Students can only work up to the selling price calculation.

2) Problem number 2

The following are examples of fragments of student answers.

Table 8. Examples of errors student answer in problem number 2

\begin{tabular}{|c|c|}
\hline Student Answers & Is there a Misconception? \\
\hline 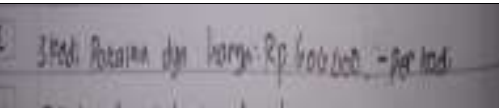 & $\begin{array}{l}\text { Misconceptions because students do } \\
\text { not understand the concept. }\end{array}$ \\
\hline 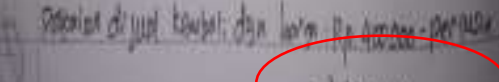 & \\
\hline
\end{tabular}

From the fragment of the student's answers, the original student answers and does not comply with the counting procedure in looking for profit. There is no calculation formula in finding selling prices, buying prices, and looking for profits. Moreover, there is no question identity as asked, answered, and a conclusion at the end of the answer.

In fragmenting the students' answers, it is suspected that they experienced misconceptions because they did not understand the concept of what to do. The students answered the questions as long as they did and were not by the profit-seeking calculation procedure. In interviews conducted with students, students mentioned that he felt difficulty filling out the questions provided and did not understand the concept; he only rewrote the problem if he could not fill in the questions. 
3) Problem number 3

From the fragments of students' answers below, the student answered the questions carelessly and did not comply with the procedure of finding the price to pay. Students do not understand the concept of using a profit-seeking formula and cannot change the form of a problem into its mathematical model. In the fragment of the students' answers, students are suspected of experiencing concept misconceptions because they cannot interpret the questions as they should and do not include identity and formulas. From interviews that have been conducted with students, students cannot answer the questions because they do not know what they have to do, students do not understand the concepts and workflow.

Table 9. Examples of errors student answer in problem number 3

\begin{tabular}{cl}
\hline Student Answers & \multicolumn{1}{c}{ Is there a Misconception? } \\
\hline $3.000=2 w_{0}^{4} / 0$ & $\begin{array}{l}\text { Concept misconceptions because } \\
\text { students cannot work on problems as } \\
\text { they should }\end{array}$ \\
\hline
\end{tabular}

4) Problem numbers 4

The following are examples of fragments of student answers.

Table 10. Examples of errors student answer in problem number 4

\begin{tabular}{cl}
\hline Student Answers & \multicolumn{2}{c}{ Is there a Misconception? } \\
\hline $4.6000030^{\circ}=110.000$ & $\begin{array}{l}\text { Concept misconceptions because } \\
\text { students cannot answer questions } \\
\text { according to concepts }\end{array}$ \\
\hline
\end{tabular}

From the fragments of students' answers above, the student answered the questions carelessly and did not comply with the procedure of finding the price to pay. Students do not understand the concept of using a formula to look for discounts, and students cannot change the form of a story problem into its mathematical model.

In solving the students' answers above, students are suspected of experiencing concept misconceptions because students cannot answer questions, include identities and formulas, and do not understand the work process. From interviews that have been conducted with students, students cannot answer the questions because they do not know what 
they have to do, students do not understand the concepts and workflow.

5) Problem numbers 5

The following are examples of fragments of student answers.

Table 11. Examples of errors student answer in problem number 5

\begin{tabular}{ll}
\hline Student Answers & \begin{tabular}{l} 
Is there a Misconception? \\
\hline $16 \times 200$
\end{tabular} \\
$\begin{array}{l}\text { Misconception because } \\
\text { students are wrong in the } \\
\text { counting process at the end. }\end{array}$ \\
\hline
\end{tabular}

From the students' answers above, students answer correctly according to looking for a single flower. Nevertheless, students immediately write answers without writing the formula and identity of the questions as they are known and asked. Moreover, students are wrong in the counting process, students should write 96,000, but students write 960,000 -.

From the fragment of the student's answer, it is suspected that the student did not experience concept misconceptions. Still, it is suspected that the students experienced misconceptions because they were wrong in the calculation process at the end of the process. Students are not careful in obtaining excessive 0 (zero) nominal. In the interviews that have been conducted with students, students mentioned that they felt confused while working on the calculation at the end of the process.

c. Students with Kinesthetic learning styles

1) Problem number 1

From the fragment of students' answers, students answer correctly by looking for profit. Nevertheless, students write answers that are not structured and are not accompanied by proper mathematical writing. Students write a nominal 100,000 to 100 and a nominal 60,000 to 60 . There are minor parts that are not filled, but there is a final answer. In fragmenting the students' answers above, it is suspected that students did not experience concept misconceptions, but students were suspected of experiencing frequent misconceptions 
because students could not complete the answers entirely and could not write the steps in a structured process.

Table 12. Examples of errors student answer in problem number 1

\begin{tabular}{lll}
\hline \multicolumn{1}{c}{ Student Answers } & \multicolumn{2}{c}{ Is there a Misconception? } \\
\hline & $\begin{array}{l}\text { Experiencing systematic } \\
\text { misconceptions because students } \\
\text { cannot complete answers } \\
\text { completely }\end{array}$ \\
\hline
\end{tabular}

From interviews conducted with students, students said that they understood seeking profit but felt confused.

2) Problem number 2

The following are examples of fragments of student answers.

Table 13. Examples of errors student answer in problem number 2

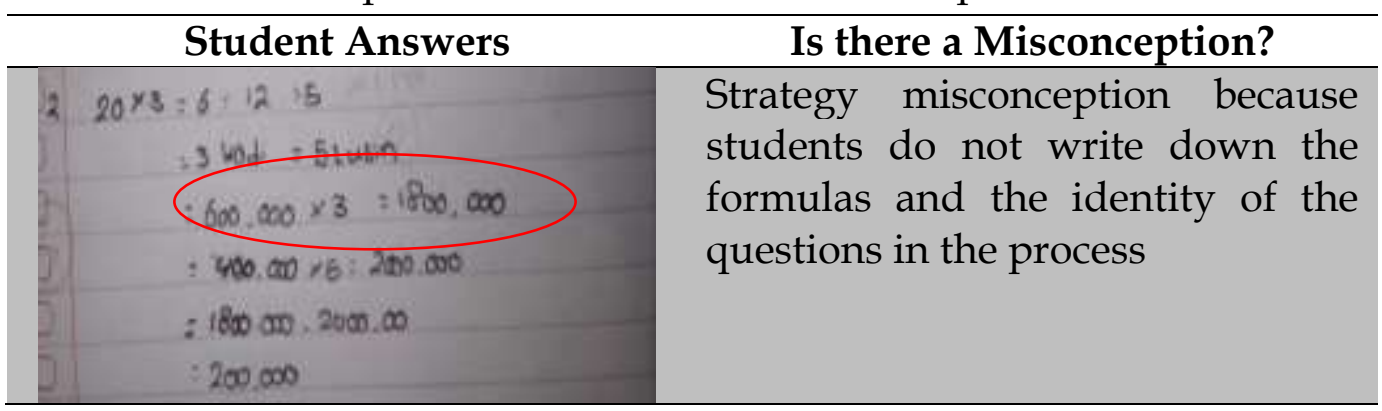

From the fragments of student answers above, students answer according to the counting procedure in looking for profit. However, students do not write down the formula for finding selling, buying, and profit formulas. Moreover, there is no question identity as known, asked, and no conclusion at the end of the answer.

In fragmenting the students' answers, it is suspected that students did not experience concept misconceptions. However, students were suspected of experiencing strategy misconceptions because students did not write down formulas in the process and the lack of emphasis from the teacher regarding the importance of the identity of questions and conclusions at the end of completion. From interviews conducted with students, students mentioned that he understood the process of working on problem number 2 , but students did not care 
about writing the identity of the questions because he felt difficulty converting words into mathematical formulas.

3) Problem number 3

The following are examples of fragments of student answers.

Table 14. Examples of errors student answer in problem number 3

\begin{tabular}{|ll}
\hline Student Answers & \multicolumn{2}{c}{ Is there a Misconception? } \\
\hline 3. $7000 \leftarrow$ & $\begin{array}{l}\text { Not yet known to experience } \\
\text { misconceptions or not. Students } \\
\text { immediately write answers }\end{array}$ \\
\hline
\end{tabular}

From the fragment of student answers, students directly answer the final result without the calculation process by the procedure in finding the value of the price to pay. In the fragment of the student answers above, it is unknown whether students experience misconceptions because they directly write the final answer. From interviews conducted with students, students said he knew that question number 3 would seek a discount, but he did not understand the concept and process. So after the interview, it is suspected that students experience concept misconceptions.

\section{4) Problem number 4}

The following are examples of fragments of student answers.

Table 15. Examples of errors student answer in problem number 4

\begin{tabular}{ll}
\hline Student Answers & \multicolumn{1}{c}{ Is there a Misconception? } \\
\hline $43000 \times 2000$ & $\begin{array}{l}\text { Misconceptions of concepts because } \\
\text { they do not know the concept of the } \\
\text { process. }\end{array}$ \\
\hline
\end{tabular}

From the fragment of student answers, students answer according to the counting process in looking for discounts, but students are wrong in the calculation process, and students immediately answer without any formulas, question identity, and conclusions. Students should write 24,000 but write 240,000 .

In the fragment of the students' answers above, students are suspected of experiencing concept misconceptions because they do not 
know the working concepts. Furthermore, in addition to the concept misconception, students are suspected of having a misconception because they are wrong in the calculation process.

From interviews conducted with students, students said that they did not understand finding discounts and prices to pay. Students fill in the problem by guessing how it should be done, and they only multiply the numbers in the problem.

5) Problem number 5

The following are examples of fragments of student answers.

Table 16. Examples of errors student answer in problem number 5

\begin{tabular}{cl}
\hline Student Answers & Is there a Misconception? \\
\hline $5 . \quad 3 \infty 000+16+2$ & $\begin{array}{l}\text { Concept misconceptions } \\
\text { because students do not } \\
\text { understand the concept } \\
=316200\end{array}$ \\
\end{tabular}

From the fragment of student answers, students write down how a single interest is correct. Still, students are wrong in giving a mathematical sign that the process should be done by multiplying the capital, presentation, and duration of saving, but students do by adding all three.

In the fragment of the students' answers above, it is suspected that students experienced concept misconceptions because students did not understand the concept of the process, including students who did not understand the mathematical formulas and marks that must be used and students who did not understand calculation process. From interviews conducted with students, students mentioned that they felt difficulty understanding the concept of looking for a single interest, including determining the mathematical formula and the calculation process.

Based on the analysis above, the following results were obtained. 
Table 17. Examples of errors student answer in problem number 5

\begin{tabular}{|c|c|c|}
\hline No & Learning style & Alleged Misconception \\
\hline 1. & Visual & $\begin{array}{l}\text { Do not experience misconceptions in } \\
\text { mathematical concepts, but students } \\
\text { experience misconceptions in the process of } \\
\text { counting and translation. }\end{array}$ \\
\hline 2. & Auditory & $\begin{array}{l}\text { There are no misconceptions about } \\
\text { mathematical concepts, but students } \\
\text { experience errors in the final calculation } \\
\text { process. }\end{array}$ \\
\hline 3. & Kinesthetic & $\begin{array}{l}\text { It is suspected that students have conceptual } \\
\text { misconceptions because students do not } \\
\text { understand the concept of the process, } \\
\text { including students who do not understand the } \\
\text { mathematical formulas and values that must } \\
\text { be used and students do not understand } \\
\text { calculations }\end{array}$ \\
\hline
\end{tabular}

Based on the data validation results, students experience various misconceptions in social arithmetic material. From some indications of misconceptions experienced by students, the character of students' misconceptions in terms of the learning styles can be seen. The things that become indicators of misconceptions in terms of learning styles are looking for profits, finding discounts, determining prices, and misconceptions about single interest.

Analysis of misconception tests in terms of visual learning styles: there is a slight concept misconception in students only in question number 4, but students who have this visual learning style experience strategic misconceptions, sign misconceptions, and translation misconceptions. The cause of strategy misconceptions, sign misconceptions, and translation misconceptions are due to students who are not careful, ignorant of formulas, and do not understand the process of problem-solving. The reasons refer to teachers who do not clearly emphasise the importance of the identity of questions and writing formulas in an answer and working process involving various variables such as percentages and nominal prices that are hundreds of thousands multiplied simultaneously.

Students who have this visual learning style tend to enjoy the process of learning mathematics because the teacher explains the material in writing and clearly on the board (Bhagat, Vyas, \& Singh, 2015; Jaleel \& Thomas, 2019). 
Because basically, students who have this visual learning style prefer the oneway learning process with lecture learning methods.

Analysis of misconception tests in terms of the Auditorial learning style results in many concept misconceptions, but in addition to concept misconceptions, students also experience translation misconceptions, strategy misconceptions, and numerical misconceptions. In the misconceptions that occur to students, the leading cause is the students' ignorance of the concept of solving social arithmetic problems, a guide book consisting of only one source, and other causes, namely the teacher who does not emphasize how important it is to write formulas in solving mathematical problems.

Students who have an auditory learning style learn by listening and remembering what is discussed rather than what they see (Corbitt, 2017; Syofyan \& Siwi, 2018). In learning mathematics, a minor experience obstacle, these obstacles are due to the teacher's learning methods in the form of lecture methods, which make students feel bored. Students who have an auditory learning style tend to want learning that engages students in their learning process, for example, through group discussions or staging plays in the buying and selling process carried out in this social arithmetic material.

Analysis of misconception tests in terms of Kinesthetic learning styles, many misconceptions occur in the questions given to students. Students cannot complete answers because they do not understand the mathematical concepts they must work on. Aside from concept misconceptions, students are also suspected of experiencing numerical, strategic, and systematic misconceptions. Various misconceptions occur because students experience preconceptions.

Students who have a kinesthetic learning style find it very difficult to learn mathematics because it is caused by teachers who provide mathematical material only by the lecture method (Metzler, 2016). While students who have a kinesthetic learning style tend to want a lively classroom atmosphere (Syofyan \& Siwi, 2018), such as games that involve student activity, and students wish to a busy class condition in the form of ice breaking every change of learning or when student conditions are felt to be no longer concentrated. Because according to students, the mathematics learning process that the teacher has done tends to be very dull. 


\section{CONCLUSION}

Based on the research and discussion above, it can be concluded that there are misconceptions about students on the subject of social arithmetic in terms of learning styles. Students who have a visual learning style do not experience misconceptions in mathematical concepts, but students experience misconceptions in the process of counting and translation. Students who have an auditory learning style have no misconceptions about mathematical concepts, but students experience errors in the final calculation process. While students have kinesthetic learning styles, it is suspected that students have conceptual misconceptions because students do not understand the concept of the process, including students who do not understand the mathematical formulas and values that must be used and do not understand calculations.

\section{REFERENCES}

Aledya, V. (2019). Kemampuan pemahaman konsep matematika pada siswa. Medan. Retrieved from https://www.researchgate.net/publication/333293321_ KEMAMPUAN_PEMAHAMAN_KONSEP_MATEMATIKA_PADA_SI SWA/link/5ce5705a458515712ebb6708/download.

Alfiani, D., Muchyidin, A., \& Izzati, N. (2019). Pengaruh penerapan model pembelajaran sscs (search, solve, create, share) terhadap miskonsepsi siswa pada soal matematika bentuk cerita. Limacon: Journal of Mathematics Education, 1(2), 49-58. Retrieved from http://jurnal.fkip. unila.ac.id/index.php/limacon/article/view/20405.

Anwar, S. (2014). Ujian nasional menjadi tolak ukur pendidikan di indonesia. Retrieved February 14, 2020, from https://www.kompasiana. com/www.syahrul.com/54f7a2bba33311fc208b45e0/ujian-nasionalmenjadi-tolak-ukur-pendidikan-di-indonesia.

Arikunto, S. (2013). Prosedur penelitian suatu pendekatan praktik. Jakarta: Rineka Cipta.

Bhagat, A., Vyas, R., \& Singh, T. (2015). Students' awareness of learning styles and their perceptions to a mixed-method approach for learning. International Journal of Applied and Basic Medical Research, 5(4), 58. https:// doi.org/10.4103/2229-516x.162281.

Bok, D. (2017). How to improve the quality of higher education. Retrieved February 14, 2020, from https://www.insidehighered.com/views/2017 
/09/21/how-improve-quality-higher-education-essay.

Bungin, H. B. (2015). Penelitian kualitatif. Jakarta: Kencana.

Corbitt, W. K. (2017). Learning styles and metacognitive awareness: How They affect the L2 listening process of at-risk students in a modified foreign language program (MFLP). Dimension. Retrieved from https:/ / files.eric.ed.gov/fulltext/EJ1207902.pdf.

DePorter, B., \& Hernacki, M. (2003). Quantum learning. Bandung: Kaifa.

Fauziah, U. (2019). Matematika ilmu penting di kehidupan sehari-hari? Retrieved February 14, 2020, from https://www.kompasiana.com/ fauziah10/5d4d86b2097f36090b2779f2/matematika-ilmu-penting-di-ke hidupan-sehari-hari.

Istiyani, R., Muchyidin, A., \& Raharjo, H. (2018). Analysis of student misconception on geometry concepts using three-tier diagnostic test. Cakrawala Pendidikan, 37(2). https:/ / doi.org/10.21831/cp.v37i2.14493.

Jaleel, S., \& Thomas, A. M. (2019). Learning styles: Theories and implications for teaching learning. San Jose: Horizon Research Publishing.

Kamil, M. (2013). Pendidikan matematika. Retrieved February 14, 2020, from https://www.kompasiana.com/m.kamil/55280bb86ea8347c158b45cd/ pendidikan-matematika-artikel.

Kemendiknas. (2006). Permendiknas nomor 22 tahun 2006. Jakarta.

Magdalena, S. M. (2015). The relationship of learning styles, learning behaviour, and learning outcomes at the Romanian students. Procedia Social and Behavioral Sciences, 180(November 2014), 1667-1672. https:// doi.org/10.1016/j.sbspro.2015.05.062.

Medina, P. (2015). Analisis miskonsepsi siswa kelas X pada materi larutan elektrolit dan non elektrolit serta reaksi oksidasi dan reduksi dalam pembelajaran kimia di SMAN Kota Padang. Jurnal Pendidikan Dan Teknologi Informasi, 2(1), 1-9. https://doi.org/10.20961/jpkim.v8i2. 26766.

Meilando, R., Idris, M., \& Murdiana, I. N. (2017). Profil pemecahan masalah aritmatika sosial siswa kelas VIII SMP Labschool Untad Palu ditinjau dari kemampuan matematika. 4 Jurnal Elektronik Pendidikan Matematika Tadulako, 5(2). Retrieved from http://jurnal.untad.ac.id/jurnal/index. 
$\mathrm{php/JEPMT/article/view/9100.}$

Meriani, E., Muchyidin, A., \& Kusmanto, H. (2019). Analysis of students misconception in completing mathematical questions using certainty of response index (CRI). Tadris: Jurnal Keguruan Dan Ilmu Tarbiyah, 4(1), 27-39. https://doi.org/10.24042/tadris.v4i1.2988.

Metzler, R. (2016). The academic effects of kinesthetic movement with multiplication fact acquisition instruction for students in third grade. In Goucher College. Maryland.

Muchyidin, A. (2014). Pengaruh strategi pembelajaran generatif terhadap kemampuan penalaran matematika siswa. Eduma: Mathematics Education Learning and Teaching, 3(1). https://doi.org/10.24235/eduma. v3i1.10.

Muchyidin, A., \& Amin, A. hildan F. (2012). Pengaruh penguasaan teorema pythagoras terhadap kemampuan siswa dalam menyelesaikan soal-soal garis singgung lingkaran kelas VIII SMPN 1 Leuwimunding. Eduma: Mathematics Education Learning and Teaching, 1(2), 55-62. https:// doi.org/10.24235/eduma.v1i2.298.

Muhardi. (2004). Kontribusi pendidikan dalam meningkatkan kualitas bangsa Indonesia. Mimbar, XX(4), 478-492. https://doi.org/10.3171/jns.2000. 93.supplement 3.0047.

Pane, A. (2017). Belajar dan pembelajaran. Fitrah, 03(2), 333-352. Retrieved from http://jurnal.iain-padangsidimpuan.ac.id/index.php/F/article/ view $/ 945 / 0$.

Rahman, R. A., Mason, J. H., \& Yusof, Y. M. (2012). Factors affecting students' change of learning behaviour. Procedia - Social and Behavioral Sciences, 56(October), 213-222. https://doi.org/10.1016/j.sbspro.2012.09.648.

Rezaeinejad, M., Azizifar, A., \& Gowhary, H. (2015). The study of learning styles and its relationship with educational achievement among Iranian high school students. Procedia - Social and Behavioral Sciences, 199, 218224. https://doi.org/10.1016/j.sbspro.2015.07.509.

Rochmad. (2010). Proses Berpikir induktif dan deduktif dalam mempelajari matematika. Kreano: Jurnal Matematika Kreatif-Inovatif, 1(2), 107-117. https:// doi.org/10.15294/kreano.v1i2.1494.

Sutama. (2019). Pengembangan kurikulum matematika: Penilaian 
pembelajaran matematika berorientasi program for international student assessment di sekolah menengah pertama. Prosiding Seminar Nasional Sultan Agung. Semarang: Unisula.

Syofyan, R., \& Siwi, M. K. (2018). The impact of visual, auditory, and kinesthetic learning styles on economics education teaching. PICEEBA, 57(Piceeba), 642-649. Padang: Universitas Negeri Padang (UNP). https:// doi.org/10.2991/ piceeba-18.2018.17.

Yulianti, M., Juniati, D., \& Khabibah, S. (2018). Mathematical writing profile of high social arithmetic ability student in solving social arithmetic problems. Journal of Physics: Conference Series, 1108. https://doi.org/ 10.1088/1742-6596/1108/1/012123. 